\title{
21. GEOCHEMISTRY OF BROKEN RIDGE SEDIMENTS ${ }^{1}$
}

\author{
Robert M. Owen ${ }^{2}$ and Andrew R. B. Zimmerman ${ }^{2}$
}

\begin{abstract}
The present study involves the analysis and interpretation of geochemical data from a suite of sediment samples recovered at ODP Hole 752A. The samples encompass the time period that includes the lithospheric extension and uplift of Broken Ridge, and they record deposition below and above the mid-Eocene angular unconformity that denotes this uplift. A Q-mode factor analysis of the geochemical data indicates that the sediments in this section are composed of a mixture of three geochemical end members that collectively account for $94.2 \%$ of the total variance in the data. An examination of interelement ratios for each of these end members suggests that they represent the following sedimentary components: (1) a biogenic component, (2) a volcanogenic component, and (3) a hydrothermal component. The flux of the biogenic component decreases almost thirtyfold across the Eocene unconformity. This drastic reduction in the deposition of biogenic materials corresponds to the almost complete disappearance of chert layers, diatoms, and siliceous microfossils and is coincident with the uplift of Broken Ridge. The volcanogenic component is similar in composition to Santonian ash recovered at Hole 755A on Broken Ridge and is the apparent source of the Fe-stained sediment that immediately overlies the angular unconformity. This finding suggests that significant amounts of Santonian ash were subaerially exposed, weathered, and redeposited and is consistent with data that suggest that the vertical uplift of Broken Ridge was both rapid and extensive. The greatest flux of hydrothermal materials is recorded in the sediments immediately below the angular unconformity. This implies that the uplift of Broken Ridge was preceded by a significant amount of rifting, during which faulting and fracturing of the lithosphere led to enhanced hydrothermal circulation. This time sequence of events is consistent with (but not necessarily diagnostic of) the passive model of lithospheric extension and uplift.
\end{abstract}

\section{INTRODUCTION}

Marine sediments typically are mixtures of sedimentary material derived from different generic sources (e.g., biogenic, hydrogenous, hydrothermal, volcanogenic ). During the past decade, many workers have been involved in the development and refinement of mathematical techniques that are capable of deconvoluting the bulk composition of a sedimentary mixture into its constituent geochemical end members and of estimating both the composition and relative amount of each end member present (Dymond, 1981; Dymond et al., 1984; Leinen and Pisias, 1984; Chen and Owen, 1989; Olivarez and Owen, 1989). The application of this approach to a downcore sequence of sediment samples results in a detailed "chemical stratigraphy," which reflects both the nature and relative intensity of the various processes that have contributed to the development of the sediment column.

The present study involves the application of this approach to a column of Eocene sediments at Broken Ridge and is aimed at developing a record of sediment compositional change during pre-, syn-, and post-uplift deposition. Weissel and Karner (1989) have summarized various lines of evidence (see the following discussion) that suggest that the uplift of Broken Ridge resulted from a "passive" rifting mechanism; that is, it was the result of mechanical unloading of the lithosphere followed by isostatic rebound, as opposed to an "active" uplift in response to thermal or dynamic processes and magmatic thickening of the crust. Sengör and Burke (1978) have suggested that active rifting follows a volcanism-uplift-rifting time sequence of tectonic events, whereas the passive rifting time sequence involves rifting-(possibly volcanism)-uplift. A detailed chemical stratigraphy of Broken Ridge sediments should enable us to determine if compositional

'Weissel, J., Peirce, J., Taylor, E., Alt, J., et al., 1991. Proc. ODP, Sci. Results, 121: College Station, TX (Ocean Drilling Program).

${ }^{2}$ Department of Geological Sciences. The University of Michigan. Ann Arbor, MI 48109-1063, U.S.A. variations within the sediment column are consistent with the proposed time sequence for a passive rifting mechanism. We anticipate that tectonic events involving volcanism and rifting should be manifested in the sediment column at Broken Ridge as significant increases (relative to background levels) in the flux of volcanogenic and hydrothermal materials, respectively. Moreover, the uplift of Broken Ridge is clearly denoted by the presence of a major angular unconformity that was penetrated by drilling at Ocean Drilling Program (ODP) Hole 752A. Thus, the sequence of tectonic events at Broken Ridge should be recorded in the composition of the geochemical end members that are present and in their position relative to each other and relative to the angular unconformity.

The upper Eocene sediments immediately overlying the angular unconformity are dark brown in color as a result of staining by iron oxide. A specific objective of this study is to employ the chemical stratigraphy methodology to determine the cause of this increased iron flux. One possible explanation is that it resulted from the weathering of volcanic ash-rich Cretaceous sediments that were exposed following the uplift of Broken Ridge. A result in support of this explanation would be consistent with estimates that Broken Ridge experienced more than $2 \mathrm{~km}$ of vertical uplift (Weissel and Karner, 1989; Rea et al., 1990). Alternatively, increased iron fluxes have been linked to episodes of suddenly enhanced hydrothermal activity at times of ridge jumps and rift initiation (Owen and Rea, 1985; Lyle et al., 1987). If this can be demonstrated at Broken Ridge, it would imply a significant degree of temporal overlap between the rifting and uplift stages during a passive rifting event.

\section{LITHOLOGIC SETTING}

Seafloor basalt, formed at anomaly 18 time (42 Ma; Houtz et al., 1977; Mutter and Cande, 1983), and a pronounced angular unconformity across Broken Ridge denote the separation of Broken Ridge from the Kerguelen Plateau and the uplift of Broken Ridge, respectively. Hole $752 \mathrm{~A}$ (located at approximately 
$30.89^{\circ} \mathrm{S}, 93.58^{\circ} \mathrm{E}$ ) was drilled north of the crest of Broken Ridge and contains an extensive record of the sediment deposited before and after the mid-Eocene uplift of the ridge. Map views of Hole $752 \mathrm{~A}$ and a cross section of the seismic stratigraphy at Broken Ridge are shown in Peirce, Weissel, et al. (1989) and are repeated here as Figures 1 and 2, respectively, for the convenience of the reader. The uppermost portion of the sedimentary section, the "pelagic cap," consists of a nannofossil ooze with foraminifers. A disconformity at about $94 \mathrm{~m}$ below seafloor (mbsf) separates ooze of Pleistocene to late Oligocene age (oldest is $30 \mathrm{Ma}$ ) from the darker brown latest Eocene ooze (youngest is $38 \mathrm{Ma}$ ). The Oligocene hiatus on Broken Ridge has been interpreted as resulting from a relative fall in sea level at this time (Rea et al., 1990), as opposed to an intensification of ocean circulation (e.g., see discussion of Oligocene hiatuses in Kennett, 1982), because of the presence of a pebble layer at the disconformity. An angular unconformity (104-113 mbsf at Hole 752A) marks the period in which Broken Ridge was uplifted. The timing of the uplift of Broken Ridge is well constrained: the oldest sediment overlying the angular unconformity is about $38 \mathrm{Ma}$ and the youngest sediment recovered from below it is about $45 \mathrm{Ma}$ (Peirce, Weissel, et al., 1989). The middle Eocene to upper Maestrichtian nannofossil calcareous (micritic) chalks and limestone underlying this unconformity dip to the north. The uppermost chalk unit (113-210 mbsf at Hole $752 \mathrm{~A}$ ) is greenish gray in color and contains volcanic ash layers and minor occurrences of chert. Both of the unconformities are overlain by sand and limestone and chert pebble layers that contain $\mathrm{Fe}$-stained quartz grains and shell hash reworked from the underlying sediment. Much of the shallow marine deposits overlying the unconformable upper Eocene erosion surface, however, were unrecovered as a result of their sandy texture. At Site 755, farther south on Broken Ridge (Figs. 1 and 2), the Eocene unconformity is underlain by volcanic tuff and $\mathrm{Fe}$-stained ashy limestone of Santonian age. Shipboard analyses of sediment in Cores $121-755 \mathrm{~A}-5 \mathrm{R}$ to $121-755 \mathrm{~A}-12 \mathrm{R}$ report ash concentrations of greater than $50 \%$ in these sediments.

\section{METHODS}

Geochemical analyses were performed on a suite of 46 samples from Hole $752 \mathrm{~A}$ that ranged in age from 19 to $57 \mathrm{Ma}$ (79.7 to $162.7 \mathrm{mbsf}$ ). The samples were taken from Sections 121-752A$9 \mathrm{H}-3$ through $121-752 \mathrm{~A}-18 \mathrm{X}-1$ at intervals of, at most, $1.5 \mathrm{~m}$; more closely spaced samples were analyzed from within the sediment overlying the Eocene unconformity (Tables 1 and 2). For comparison purposes, identical analyses were also performed on a suite of 10 samples of Santonian ash-rich sediments recovered from Cores 121-755A-5R to 121-755A-9R. All samples, consisting of 1 - to $2-\mathrm{cm}$ sections of core, were weighed, freezedried, and reweighed to calculate the dry-bulk density. The samples were then ground with mortar and pestle and homogenized. Carbonate content was determined using a conventional pressure bomb technique. All elemental abundances were determined by instrumental neutron activation analysis (INAA) at the Phoenix Memorial Laboratory, The University of Michigan, using stand-

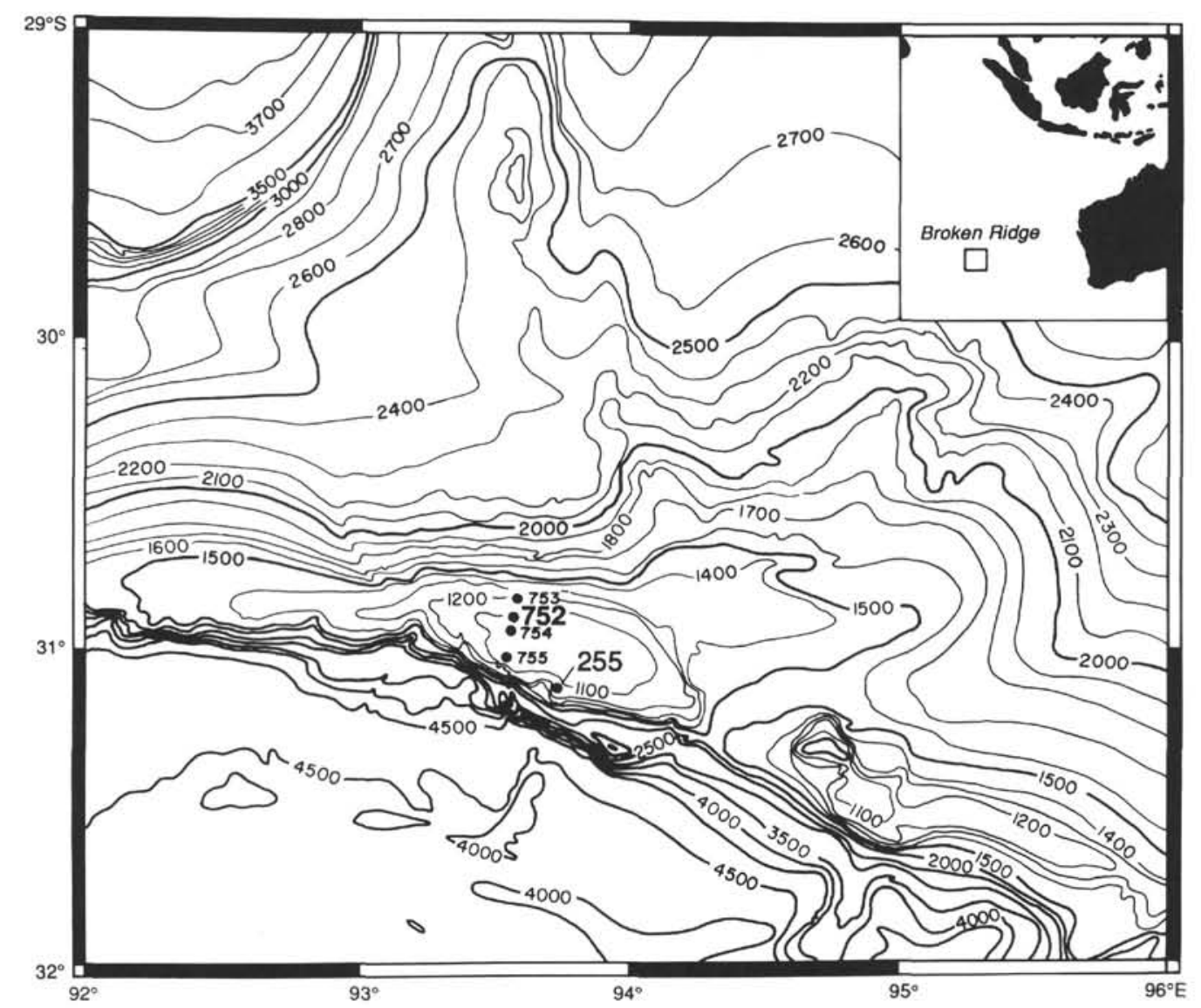

Figure 1. Bathymetric map showing location of ODP Site 752, DSDP Site 255, and other Leg 121 sites at Broken Ridge. Contours are shown at 100-m intervals, except along the south-facing escarpment where contours are omitted for clarity (from Peirce, Weissel, et al., 1989). 


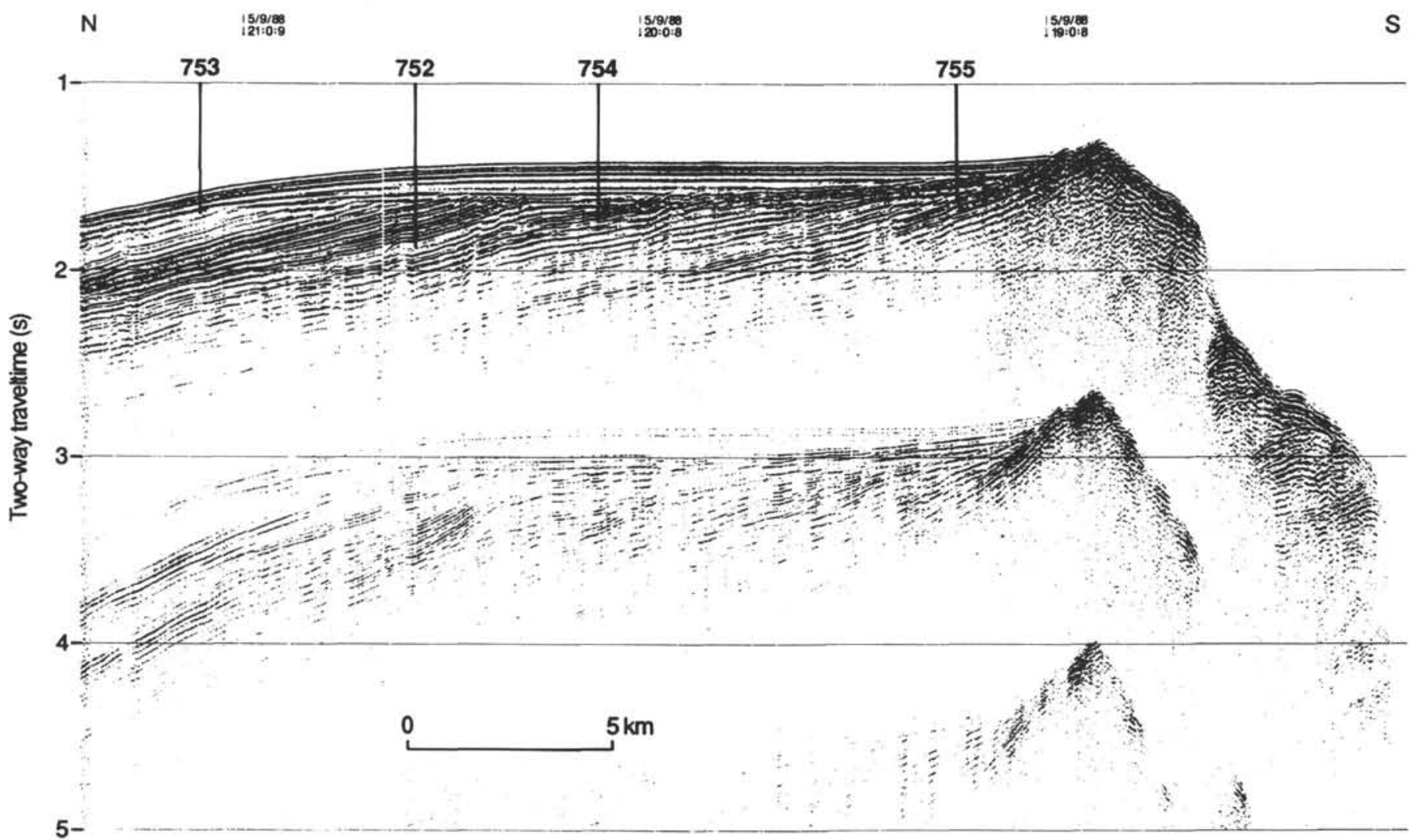

Figure 2. Seismic stratigraphy showing Leg 121 sites at Broken Ridge (from Peirce, Weissel, et al., 1989).

ard INAA procedures (Gordon et al., 1968; Dams and Robbins, 1970). Replicate analyses of NBS-1633A standard as well as "Standard Pacific Sediment" (Owen and Ruhlin, 1986) were performed to evaluate analytical precision (see Owen and Zimmerman, this volume).

The statistical methods employed in this study are designed to discriminate between different types of sediment in the samples and to determine the relative contribution of each type to any given sediment sample. Both the number and the chemical composition of the major geochemical end members in our samples are determined by a quantitative sediment partitioning procedure, which involves a mathematical manipulation of the geochemical data set using multivariant Q-mode factor analysis and vector rotation according to the technique of Leinen and Pisias (1984). The chemical significance (i.e., the nature of the source material) of each end member identified by this procedure is determined by comparing key interelement ratios within each end member with analogous ratios reported in the literature and known to be characteristic of pure geochemical source materials (Dymond, 1981; Graybeal and Heath, 1984; Leinen and Pisias, 1984). The relative amount of each end member in each sample is determined by a linear programming procedure that provides an optimum solution (minimum error) for each sample. The computer programs needed to implement this technique were kindly provided to us by Drs. M. Leinen and N. Pisias. Finally, the total sediment mass-accumulation rate (MAR) is calculated as the product of the dry-bulk density and the linear sedimentation rate. The MAR, or flux of each end-member component to the sediment at any given time, is the product of the whole-sediment MAR and the fraction of a sample's composition that each end member represents. The MARs of each sediment end member identified by the factor analysis were calculated using the linear sedimentation rates and age-depth correlations reported in Table 3, the dry-bulk densities measured in this study, and the relative abundance of each end member in each sample as determined by linear programming.

\section{RESULTS AND DISCUSSION}

\section{Identification of Geochemical End Members}

The concentrations of 15 elements and the whole-sediment MARs determined for the samples analyzed in this study are shown in Tables 1 and 2. The factor analysis identified three factors that collectively account for $94.2 \%$ of the data; the estimated composition of each of these factors, or geochemical end members, is shown in Table 4.

The first end member, factor 1 , is interpreted as a biogenic (i.e., biogenic opal and refractory organic matter) end member. Several interelemental ratios of this end member, such as $\mathrm{Mn} / \mathrm{Ba}, \mathrm{Al} / \mathrm{Ba}$, $\mathrm{Co} / \mathrm{Ba}$, and $\mathrm{Mn} / \mathrm{Al}$, are in close agreement with analogous ratios reported in the literature and considered to be characteristic of sedimentary biogenic material (Table 5). All of the Ba and the highest loading of Mn are associated with factor 1 (Table 4); Mn is enriched in phytoplankton (Riley and Roth, 1971; Martin and Knauer, 1973) and Ba is strongly associated with biogenic sediments (Gurvich et al., 1978; Dehairs et al., 1980) and is generally regarded as a proxy indicator of biological productivity (Boström et al., 1973; Schmitz, 1987). The MAR of factor 1 (Fig. 3A) reveals a sharp decrease in the rate of biogenic sedimentation across the middle Eocene unconformity. This is consistent with shipboard observations that note an almost complete absence of chert layers, diatoms, and other siliceous microfossils in sediment younger than early Eocene in age (Peirce, Weissel, et al., 1989). This drastic change in biogenic sedimentation, from accumulation rates of 1.1 to $0.04 \mathrm{~g} / \mathrm{cm}^{2} / 1000 \mathrm{yr}$ (Fig. 3A), may be partly explained by the movement of the ridge away from productive high-latitude regions or by a reduction in bathymetrically induced 
Table 1. Major and trace element composition and whole-sediment mass-accumulation rates of Broken Ridge sediments.

\begin{tabular}{|c|c|c|c|c|c|c|c|c|c|}
\hline $\begin{array}{l}\text { Core, section, } \\
\text { interval }(\mathrm{cm})\end{array}$ & $\begin{array}{l}\text { Depth } \\
\text { (mbsf) }\end{array}$ & $\begin{array}{l}\text { Al } \\
(\%)\end{array}$ & $\begin{array}{l}\mathrm{Mn} \\
(\%)\end{array}$ & $\begin{array}{l}\mathrm{Ba} \\
(\%)\end{array}$ & $\begin{array}{l}\mathrm{Fe} \\
(\%)\end{array}$ & $\begin{array}{l}\text { Co } \\
\text { (ppm) }\end{array}$ & $\begin{array}{l}\text { Sc } \\
(\mathrm{ppm})\end{array}$ & $\begin{array}{l}\mathrm{Zn} \\
(\mathrm{ppm})\end{array}$ & $\begin{array}{l}\text { Whole-sediment } \\
\text { Mass-accumulation rat } \\
\left(g^{\prime} \mathrm{cm}^{2} / 1000 \mathrm{yr}\right)\end{array}$ \\
\hline \multicolumn{10}{|l|}{ 121-752A- } \\
\hline $9 \mathrm{H}-3,125-130$ & 79.70 & 4.55 & 0.212 & $<0.080$ & 1.84 & 35.3 & 6.81 & $<79.5$ & 0.334 \\
\hline $9 \mathrm{H}-4,110-115$ & 81.00 & 3.26 & 0.410 & $<0.142$ & 2.12 & 42.0 & 13.6 & 300 & 0.340 \\
\hline $9 \mathrm{H}-5,125-130$ & 82.70 & 3.56 & 0.275 & 0.137 & 2.45 & 43.8 & 11.5 & 291 & 0.330 \\
\hline $10 \mathrm{H}-1,130-135$ & 86.30 & 7.21 & 0.558 & 0.228 & 4.25 & 101 & 19.9 & 437 & 0.286 \\
\hline $10 \mathrm{H}-2,130-135$ & 87.80 & 4.62 & 0.692 & 0.356 & 3.92 & 125 & 22.0 & 459 & 0.281 \\
\hline $10 \mathrm{H}-3,130-135$ & 89.30 & 3.85 & 0.714 & 0.320 & 4.01 & 152 & 20.0 & 341 & 0.274 \\
\hline $10 \mathrm{H}-4,130-135$ & 90.80 & 1.92 & 0.305 & 0.183 & 2.86 & 66.7 & 11.5 & 169 & 0.274 \\
\hline $10 \mathrm{H}-5,130-135$ & 92.30 & 2.98 & 0.306 & 0.192 & 5.19 & 102 & 13.8 & 153 & 0.042 \\
\hline $10 \mathrm{H}-6,130-135$ & 93.80 & 2.61 & 0.130 & 0.0533 & 13.0 & 13.4 & 16.6 & 407 & 0.080 \\
\hline $10 \mathrm{H}-7,20-25$ & 94.20 & 3.39 & 0.113 & $<0.040$ & 16.1 & 17.1 & 19.1 & 396 & 0.125 \\
\hline $10 \mathrm{H}-7,55-60$ & 94.55 & 4.70 & 0.232 & $<0.030$ & 16.3 & 50.1 & 24.1 & 467 & 0.170 \\
\hline $11 \mathrm{H}-1,60-65$ & 95.30 & 4.29 & 0.105 & 0.0325 & 13.0 & 23.5 & 20.6 & 328 & 0.237 \\
\hline $11 \mathrm{H}-1,130-135$ & 96.00 & 3.94 & 0.161 & 0.0372 & 11.3 & 20.2 & 18.1 & 260 & 0.324 \\
\hline $11 \mathrm{H}-2,60-65$ & 96.80 & 3.10 & 0.145 & 0.0303 & 10.8 & 21.1 & 16.0 & 228 & 0.420 \\
\hline $11 \mathrm{H}-2,130-135$ & 97.50 & 2.58 & 0.108 & 0.0103 & 9.38 & 18.2 & 13.8 & 206 & 0.492 \\
\hline $11 \mathrm{H}-3,60-65$ & 98.30 & 2.00 & 0.0712 & $<0.017$ & 6.64 & 13.0 & 11.2 & 160 & 0.639 \\
\hline $11 \mathrm{H}-3,130-135$ & 99.00 & 1.82 & 0.0416 & $<0.015$ & 3.70 & 8.40 & 7.49 & 86.4 & 0.732 \\
\hline $11 \mathrm{H}-4,60-65$ & 99.80 & 1.26 & 0.0259 & $<0.014$ & 2.94 & 6.72 & 6.72 & 59.1 & 0.891 \\
\hline $11 \mathrm{H}-4,120-125$ & 100.40 & 1.40 & 0.0243 & $<0.018$ & 2.49 & 6.46 & 7.25 & 50.4 & 0.845 \\
\hline $11 \mathrm{H}-5,60-65$ & 101.30 & 1.36 & 0.0220 & 0.0237 & 1.81 & 4.74 & 5.45 & 67.9 & 1.04 \\
\hline $11 \mathrm{H}-5,130-135$ & 102.00 & 1.74 & 0.0308 & 0.0333 & 2.09 & 5.12 & 7.42 & 71.7 & 1.11 \\
\hline $11 \mathrm{H}-6,60-65$ & 102.80 & 1.66 & 0.0280 & $<0.027$ & 1.95 & 4.67 & 6.63 & 40.0 & 1.23 \\
\hline $12 \mathrm{X}-1,10-12$ & 103.40 & 1.53 & 0.0555 & 0.0317 & 2.18 & 66.1 & 7.46 & 82.8 & 1.37 \\
\hline $11 \mathrm{H}-6,125-130$ & 103.45 & 1.24 & 0.0189 & $<0.019$ & 1.70 & 3.71 & 5.27 & 48.5 & 1.67 \\
\hline $12 X-1,20-22$ & 103.50 & 3.79 & 0.149 & $<0.046$ & 5.83 & 39.3 & 15.3 & 191 & 1.48 \\
\hline $13 X-1,135-140$ & 114.25 & 5.47 & 0.742 & 6.16 & 3.65 & 20.0 & 31.4 & 211 & 2.71 \\
\hline $13 X-2,130-135$ & 115.70 & 2.27 & 0.836 & 4.84 & 2.57 & 13.6 & 25.4 & 232 & 2.92 \\
\hline $13 x-3,100-105$ & 116.90 & 5.64 & 0.618 & 0.456 & 4.19 & 25.3 & 33.6 & 502 & 2.87 \\
\hline $13 x-4,52-57$ & 117.92 & 3.38 & 0.315 & 3.00 & 2.70 & 19.3 & 17.7 & 296 & 2.65 \\
\hline $14 \mathrm{X}-1,130-135$ & 123.90 & 3.05 & 0.114 & 0.705 & 3.44 & 19.2 & 16.4 & 106 & 2.67 \\
\hline $14 X-2,130-135$ & 125.40 & 3.33 & 0.161 & 1.05 & 3.85 & 23.2 & 17.8 & 184 & 2.71 \\
\hline $14 X-3,130-135$ & 126.90 & 3.64 & 0.181 & 1.11 & 2.24 & 12.9 & 11.4 & 110 & 2.79 \\
\hline $14 X-4,130-135$ & 128.40 & 2.19 & 0.166 & 1.02 & 1.91 & 10.7 & 10.8 & 43.8 & 2.95 \\
\hline $15 X-1,130-135$ & 133.60 & 2.47 & 0.180 & 0.900 & 2.66 & 16.7 & 11.5 & 98.1 & 3.34 \\
\hline $15 X-2,130-135$ & 135.10 & 3.26 & 0.215 & 1.09 & 3.51 & 18.6 & 17.5 & 183 & 3.29 \\
\hline $15 X-3,130-135$ & 136.60 & 5.48 & 0.0650 & $<0.042$ & 2.11 & 11.9 & 5.07 & 109 & 2.74 \\
\hline $15 X-4,130-135$ & 138.10 & 1.28 & $<0.0031$ & 0.518 & 1.46 & 7.14 & 6.80 & 52.3 & 2.81 \\
\hline $15 X-5,110-115$ & 139.39 & 3.65 & 0.103 & 0.740 & 3.39 & 25.1 & 12.7 & 92.6 & 2.87 \\
\hline $16 \mathrm{X}-1,130-135$ & 143.30 & 2.18 & 0.211 & 1.39 & 1.64 & 12.1 & 12.1 & 174 & 3.00 \\
\hline $16 \mathrm{X}-2,130-135$ & 144.80 & 1.28 & 0.114 & 1.12 & 1.63 & 9.98 & 8.60 & 114 & 2.93 \\
\hline $16 \mathrm{X}-3,105-110$ & 146.05 & 2.22 & 0.170 & 1.35 & 1.99 & 10.3 & 10.9 & 101 & 3.24 \\
\hline $16 X-4,130-135$ & 147.80 & 2.59 & 0.176 & 1.22 & 1.62 & 9.43 & 10.8 & 120 & 3.53 \\
\hline $17 X-1,130-135$ & 153.00 & 2.57 & 0.121 & 0.901 & 2.78 & 15.5 & 14.1 & 138 & 2.97 \\
\hline $17 X-2,130-135$ & 154.50 & 3.61 & 0.176 & 1.09 & 3.97 & 25.4 & 22.6 & 87.3 & 3.36 \\
\hline $17 X-3,125-130$ & 155.95 & 4.14 & 0.104 & 0.651 & 4.58 & 29.4 & 20.7 & 214 & 2.91 \\
\hline $18 X-1,130-135$ & 162.70 & 3.84 & 0.195 & 0.932 & 3.76 & 27.0 & 20.0 & 117 & 3.15 \\
\hline
\end{tabular}

upwelling coincident with subsidence of the ridge (Rea et al., 1990).

Factor 2 is extremely $\mathrm{Fe}$ rich and represents about $80 \%$ of the composition of the sediment immediately overlying the middle Eocene unconformity (Fig. 3B). The composition of this end member estimated from factor analysis (Table 4) is considered representative of the $\mathrm{Fe}$-stained Eocene sediments described previously. A clear interpretation of the source of the $\mathrm{Fe}$ in these sediments is especially important to understanding the rifting mechanism at Broken Ridge. For example, if the source of this $\mathrm{Fe}$ is hydrothermal, then the presence of abundant hydrothermal materials in the post-uplift sediments would suggest that there is a considerable degree of temporal overlap between the rifting and uplift stages of a passive rifting event.

The $\mathrm{Mn} / \mathrm{Fe}$ ratio of factor $2(0.00521)$ is more than 2 orders of magnitude lower than that characteristic of common Fe-rich sedimentary components, such as hydrogenous material $(\mathrm{Mn} / \mathrm{Fe}=$
1.0-1.5; Dymond et al., 1984; Palmer and Elderfield, 1986), hydrothermal material $(\mathrm{Mn} / \mathrm{Fe}=0.29-0.43$; Dymond, 1981; Greybeal and Heath, 1984; Ruhlin and Owen, 1986a, 1986b), or ferromanganous oxyhydroxide products of oxic or suboxic diagenesis $(\mathrm{Mn} / \mathrm{Fe}=5-70$; Dymond et al., 1984; Chen and Owen, 1989). The only other likely source of iron at Broken Ridge is derivation from subaerial or shallow submarine weathering of underlying Cretaceous sediments that were uplifted. Volcanic ash is ubiquitous throughout the pre-rift section, although in diminishing abundance upsection. The youngest sediments that are both rich in $\mathrm{Fe}$ and underlie the angular unconformity are ashy limestones of Santonian age that were recovered at Site 755 . To explore this possibility, we have analyzed 10 samples of Santonian ash recovered from Cores 121-755A-5R through 121-755A$9 \mathrm{R}$, calculated various interelement ratios from the mean values of these analyses, and compared these to analogous ratios calculated from factor 2. The results of this comparison (Table 6) 
Table 2. Rare earth element composition of Broken Ridge sediments.

\begin{tabular}{|c|c|c|c|c|c|c|c|c|c|}
\hline $\begin{array}{l}\text { Core, section, } \\
\text { interval }(\mathrm{cm})\end{array}$ & $\begin{array}{l}\text { Depth } \\
\text { (mbsf) }\end{array}$ & $\begin{array}{c}\mathrm{La} \\
(\mathrm{ppm})\end{array}$ & $\begin{array}{c}\mathrm{Ce} \\
(\mathrm{ppm})\end{array}$ & $\begin{array}{l}\mathrm{Nd} \\
(\mathrm{ppm})\end{array}$ & $\underset{(p p m)}{S m}$ & $\begin{array}{l}\text { Eu } \\
(\mathrm{ppm})\end{array}$ & $\begin{array}{c}\text { Dy } \\
(\mathrm{ppm})\end{array}$ & $\begin{array}{c}\mathrm{Yb} \\
(\mathrm{ppm})\end{array}$ & $\begin{array}{l}\text { Lu } \\
(\mathrm{ppm})\end{array}$ \\
\hline \multicolumn{10}{|l|}{$121-752 A-$} \\
\hline $9 \mathrm{H}-3,125-130$ & 79.70 & 107 & 105 & 151 & 16.1 & 3.64 & 12.2 & 10.7 & 1.27 \\
\hline $9 \mathrm{H}-4,110-115$ & 81.00 & 166 & 119 & 172 & 26.4 & 5.90 & 35.8 & 19.0 & 2.56 \\
\hline $9 \mathrm{H}-5,125-130$ & 82.70 & 161 & 172 & 241 & 23.6 & 4.43 & 23.6 & 14.8 & 2.16 \\
\hline $10 \mathrm{H}-1,130-135$ & 86.30 & 220 & 252 & 654 & 35.2 & 5.92 & 42.9 & 21.4 & 2.92 \\
\hline $10 \mathrm{H}-2,130-135$ & 87.80 & 278 & 196 & 518 & 44.6 & 9.90 & 71.3 & 31.1 & 4.27 \\
\hline $10 \mathrm{H}-3,130-135$ & 89.30 & 247 & 221 & 697 & 40.3 & 7.78 & $\mathbf{5 7 . 7}$ & 28.9 & 3.74 \\
\hline $10 \mathrm{H}-4,130-135$ & 90.80 & 138 & 62.3 & 202 & 22.4 & 3.45 & 28.6 & 13.6 & 1.83 \\
\hline $10 \mathrm{H}-5,130-135$ & 92.30 & 151 & 99.3 & 190 & 23.3 & 7.79 & 27.7 & 15.5 & 1.60 \\
\hline $10 \mathrm{H}-6,130-135$ & 93.80 & 240 & 69.7 & 195 & 33.7 & 7.43 & 41.0 & 15.6 & 2.42 \\
\hline $10 \mathrm{H}-7,2 \mathrm{O}-25$ & 94.20 & 244 & 68.7 & 212 & 36.9 & 7.84 & 34.8 & 15.2 & 1.95 \\
\hline $10 \mathrm{H}-7,55-60$ & 94.55 & 99.9 & 89.4 & 100 & 18.0 & 3.99 & 16.8 & 8.23 & 1.18 \\
\hline $11 \mathrm{H}-1,60-65$ & 95.30 & 71.5 & 74.4 & 77.6 & 12.5 & 2.57 & 12.4 & 7.44 & 0.897 \\
\hline $11 \mathrm{H}-1,130-135$ & 96.00 & 67.5 & 65.1 & 66.7 & 11.2 & 2.49 & 13.3 & 6.59 & 0.857 \\
\hline $11 \mathrm{H}-2,60-65$ & 96.80 & 74.7 & 61.3 & 85.2 & 12.0 & 2.34 & 12.6 & 6.49 & 0.845 \\
\hline $11 \mathrm{H}-2,130-135$ & 97.50 & 67.2 & 50.1 & 50.1 & 10.5 & 2.32 & 12.2 & 5.78 & 0.721 \\
\hline $11 \mathrm{H}-3,60-65$ & 98.30 & 45.8 & 20.8 & 42.5 & 7.39 & 1.48 & 6.50 & 4.14 & 0.496 \\
\hline $11 \mathrm{H}-3,130-135$ & 99.00 & 25.7 & 22.2 & 23.8 & 4.16 & 0.907 & 5.35 & 2.48 & 0.315 \\
\hline $11 \mathrm{H}-4,60-65$ & 99.80 & 22.6 & 20.9 & 32.8 & 3.69 & 0.823 & 4.69 & 2.38 & 0.307 \\
\hline $11 \mathrm{H}-4,120-125$ & 100.40 & 21.1 & 25.6 & 58.2 & 3.19 & 0.781 & 2.64 & 2.17 & 0.336 \\
\hline $11 \mathrm{H}-5,60-65$ & 101.30 & 23.2 & 7.74 & 17.7 & 3.41 & 0.807 & 3.63 & 2.05 & 0.365 \\
\hline $11 \mathrm{H}-5,130-135$ & 102.00 & 28.2 & 12.5 & 30.2 & 4.10 & 0.958 & 3.14 & 2.60 & 0.257 \\
\hline $11 \mathrm{H}-6,60-65$ & 102.80 & 28.0 & 12.9 & 11.7 & 4.12 & 0.730 & 3.18 & 1.96 & 0.272 \\
\hline $12 X-1,10-12$ & 103.40 & 48.1 & 22.1 & 29.6 & 5.55 & 1.12 & 4.57 & 3.36 & 0.362 \\
\hline $11 \mathrm{H}-6,125-130$ & 103.45 & 24.6 & 25.3 & 39.2 & 3.67 & 0.722 & 3.81 & 1.98 & 0.246 \\
\hline $12 X-1,20-22$ & 103.50 & 70.6 & 35.5 & 81.8 & 10.0 & 1.80 & 12.7 & 5.56 & 0.520 \\
\hline $13 X-1,135-140$ & 114.25 & 420 & 167 & 304 & 58.9 & 8.69 & 51.3 & 34.9 & 4.76 \\
\hline $13 X-2,130-135$ & 115.70 & 388 & 100 & 572 & 50.6 & 7.98 & 51.6 & 34.8 & 3.65 \\
\hline $13 x-3,100-105$ & 116.90 & 313 & 90.2 & 253 & 42.1 & 8.69 & 25.9 & 26.3 & 3.55 \\
\hline $13 X-4,52-57$ & 117.92 & 189 & 59.4 & 262 & 27.0 & 4.61 & 16.3 & 15.8 & 2.05 \\
\hline $14 X-1,130-135$ & 123.90 & 40.3 & 47.4 & 41.3 & 6.48 & 1.85 & 4.94 & 4.78 & 0.616 \\
\hline $14 X-2,130-135$ & 125.40 & 51.0 & 41.7 & $<48.6$ & 8.32 & 2.18 & 8.81 & 7.51 & 0.805 \\
\hline $14 X-3,130-135$ & 126.90 & 59.0 & 41.0 & 71.0 & 8.87 & 2.21 & 9.76 & 5.92 & 0.941 \\
\hline $14 X-4,130-135$ & 128.40 & 52.5 & 29.4 & $<53.5$ & 7.96 & 2.24 & 8.38 & 6.60 & 0.939 \\
\hline $15 X-1,130-135$ & 133.60 & 49.1 & 31.4 & $<60.5$ & 6.92 & 1.86 & 8.53 & 6.46 & 0.799 \\
\hline $15 X-2,130-135$ & 135.10 & 59.4 & 37.7 & $<62.8$ & 9.55 & 2.69 & 12.4 & 7.74 & 1.02 \\
\hline $15 X-3,130-135$ & 136.60 & 61.7 & 130 & 52.2 & 15.6 & 1.94 & 18.3 & 12.2 & 1.50 \\
\hline $15 X-4,130-135$ & 138.10 & 25.4 & 13.3 & 42.5 & 3.93 & 1.08 & 3.90 & 3.21 & 0.300 \\
\hline $15 X-5,110-115$ & 139.39 & 41.4 & 31.9 & 56.3 & 6.95 & 1.51 & 6.72 & 6.04 & 0.627 \\
\hline $16 \mathrm{X}-1,130-135$ & 143.30 & 60.5 & 17.1 & 115 & 8.66 & 2.29 & 14.0 & 6.21 & 1.29 \\
\hline $16 X-2,130-135$ & 144.80 & 40.4 & 21.0 & $<47.8$ & 6.31 & 2.05 & $<6.31$ & 5.68 & 0.460 \\
\hline $16 X-3,105-110$ & 146.05 & 55.2 & 26.4 & 118 & 8.27 & 2.23 & 14.2 & 5.69 & 0.872 \\
\hline $16 X-4,130-135$ & 147.80 & 53.9 & 30.7 & 83.4 & 7.71 & 2.27 & 5.93 & 5.59 & 0.789 \\
\hline $17 X-1,130-135$ & 153.00 & 58.2 & 37.9 & 75.6 & 8.90 & 2.39 & 12.4 & 6.95 & 0.947 \\
\hline $17 X-2,130-135$ & 154.50 & 61.5 & 36.9 & 64.8 & 9.91 & 2.99 & 11.1 & 7.93 & 1.07 \\
\hline $17 X-3,125-130$ & 155.95 & 34.3 & 30.6 & 70.9 & 6.21 & 2.15 & 9.45 & 5.50 & 0.663 \\
\hline $18 X-1,130-135$ & 162.70 & 63.2 & 49.6 & 131 & 9.92 & 2.30 & 14.7 & 6.87 & 1.15 \\
\hline
\end{tabular}

Table 3. Age-depth correlation for Hole 752A.

\begin{tabular}{|c|c|c|c|}
\hline $\begin{array}{l}\text { Age } \\
\text { (Ma) }\end{array}$ & $\begin{array}{l}\text { Depth } \\
\text { (mbsf) }\end{array}$ & Linear \& & $\begin{array}{l}\text { sedimentation rate } \\
(\mathrm{cm} / 1000 \mathrm{yr})\end{array}$ \\
\hline $\begin{array}{l}17.1-23.7 \\
23.7-28.1\end{array}$ & $\begin{array}{l}73.1 \cdot 91.7 \\
91.7-93.4\end{array}$ & \multirow{2}{*}{ Disconformity } & $\begin{array}{l}0.28 \\
0.04\end{array}$ \\
\hline 37.8 & 104.3 & & \\
\hline $55.3-57.8$ & $115.6 \cdot 171.3$ & & 2.23 \\
\hline
\end{tabular}

a From Peirce, Weissel, et al., 1989 
Table 4. Geochemical end-member composition of Broken Ridge sediments determined by factor analysis.

\begin{tabular}{lrrr}
\hline Element & Factor 1 & Factor 2 & Factor 3 \\
\hline $\mathrm{Al}(\%)$ & 15.9 & 17.8 & 5.2 \\
$\mathrm{Fe}(\%)$ & 0.00 & 41.8 & 1.46 \\
$\mathrm{Mn}(\%)$ & 1.35 & 0.218 & 0.670 \\
$\mathrm{Ba}(\%)$ & 14.5 & 0.00 & 0.00 \\
& & & \\
$\mathrm{Zn}(\mathrm{ppm})$ & 531 & 948 & 352 \\
$\mathrm{Sc}(\mathrm{ppm})$ & 94.1 & 84.5 & 12.3 \\
$\mathrm{Co}(\mathrm{ppm})$ & 19.1 & 68.1 & 139 \\
$\mathrm{La}(\mathrm{ppm})$ & 368 & 227 & 339 \\
$\mathrm{Ce}(\mathrm{ppm})$ & 95 & 177 & 257 \\
$\mathrm{Nd}(\mathrm{ppm})$ & 511 & 156 & 558 \\
$\mathrm{Sm}(\mathrm{ppm})$ & 51.4 & 37.2 & 51.7 \\
Eu (ppm) & 15.1 & 8.78 & 9.74 \\
Dy (ppm) & 54.0 & 36.2 & 61.6 \\
Yb (ppm) & 48.3 & 20.1 & 32.7 \\
Lu (ppm) & 6.35 & 2.53 & 4.32 \\
\% of total & & & \\
Variance & 35.4 & 36.5 & 22.3 \\
\% cummulative variance & $=94.2$ & \\
\hline
\end{tabular}

indicate a strong similarity between the compositions of factor 2 and the Santonian ash samples. This similarity is also evident in a comparison of the rare earth element (REE) patterns of factor 2 and the Santonian ash samples (Fig. 4). A minor difference between these REE patterns is that, relative to Santonian ash, factor 2 exhibits a greater degree of $\mathrm{La}$ enrichment and Ce depletion. These differences, however, are consistent with the type of REE pattern expected for volcanogenic sediment that has been altered by exposure to seawater and/or mixed with $\mathrm{Ce}$-poor biogenic calcite or chert (Fleet et al., 1976; Shimizu and Misuda, 1977; Ludden and Thompson, 1978; Desprairies and Bonnot-Courtois, 1980).

The interpretation that factor 2 represents volcanogenic material is also supported by the fact that there is a close correspondence between the largest spikes in the MAR record (Fig. 3B) of factor 2 (e.g., at 124-126 and $138 \mathrm{mbsf}$ ) and the location of ash layers in the sediment section below the Eocene unconformity which were visually identified during the shipboard examination of sediments recovered at Site 752 (Peirce, Weissel, et al., 1989).

Factor 3 , which accounts for $22.3 \%$ of the variability in the data set, is interpreted as a hydrothermal end member on the basis of the comparison of interelement ratios summarized in Table 7. The interelement ratios shown in Table 7 emphasize $\mathrm{Fe}, \mathrm{Mn}$, and the REEs, whereas we have deliberately avoided using ratios

Table 5. Comparison of elemental ratios of factor 1 (Table 4) vs. literature values for biogenic sediments.

\begin{tabular}{lll}
\hline Ratio & Factor 1 & Biogenic sedimenta \\
& & \\
\hline $\mathrm{Mn} / \mathrm{Ba}$ & 0.0931 & $0.0633-0.0978$ \\
$\mathrm{~A} 1 / \mathrm{Ba}$ & 1.10 & $1.00-2.26$ \\
$\mathrm{Co} / \mathrm{Ba}$ & 0.000132 & 0.000710 \\
$\mathrm{Mn} / \mathrm{Al}$ & 0.0849 & 0.0433
\end{tabular}

Values from Leinen and Pisias (1984), Graybeal and Heath

(1984), and references therein.

A

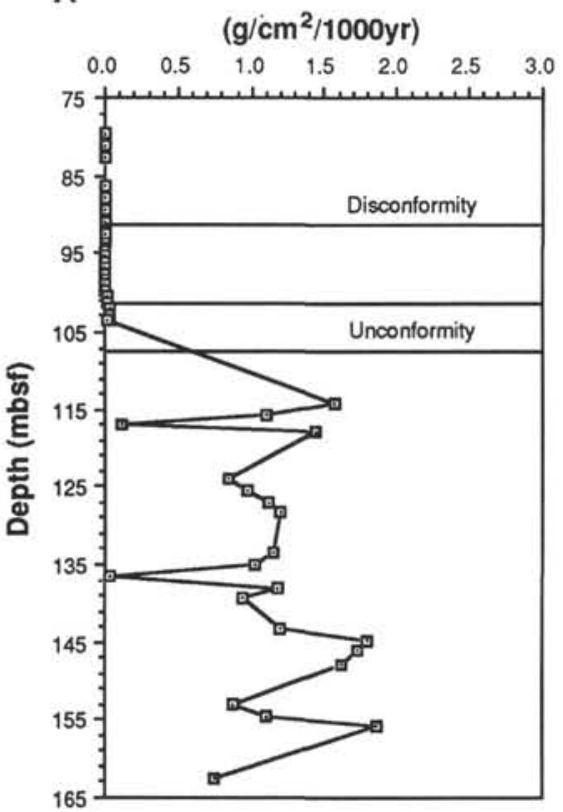

B

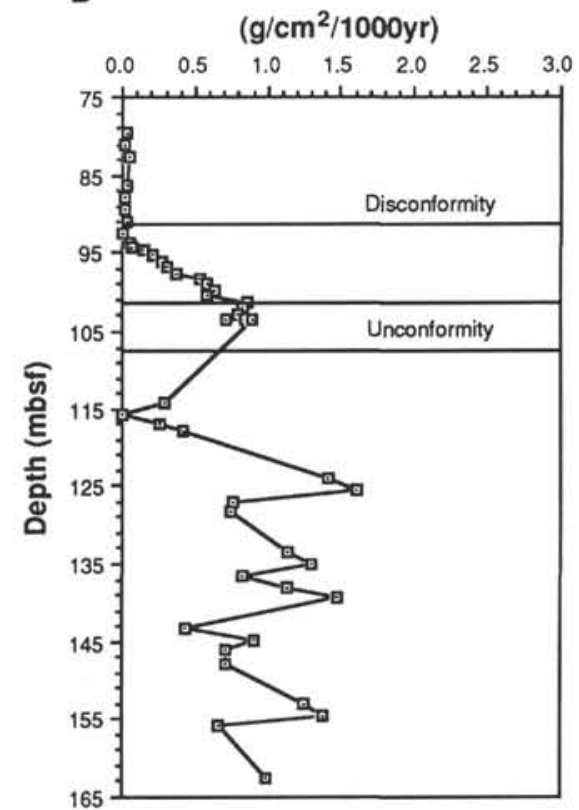

C

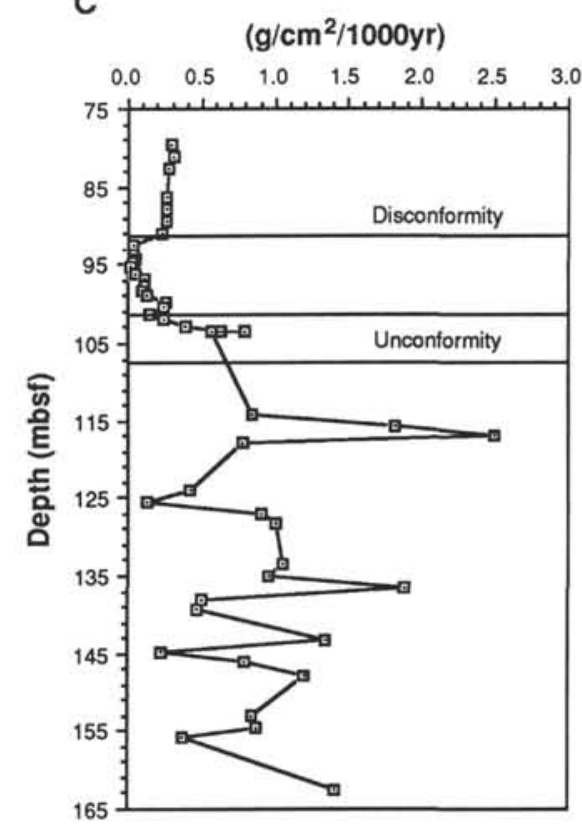

Figure 3. Mass-accumulation rates of geochemical end members in Broken Ridge sediments. MARs for each end member are calculated as the product of the whole-sediment MAR (Table 1) times the relative amount of the end member in each sample. A. Factor 1 (biogenic component). B. Factor 2 (volcanogenic component). C. Factor 3 (hydrothermal component). 
Table 6. Comparison of elemental ratios of factor 2 (Table 4) vs. Santonian ash values.

\begin{tabular}{lll}
\hline Ratio & Factor 2 & Santonian asha \\
\hline $\mathrm{Al} / \mathrm{Fe}$ & 0.426 & 0.619 \\
$\mathrm{Mn} / \mathrm{Fe}$ & 0.00521 & 0.0143 \\
$\mathrm{Zn} / \mathrm{Fe}$ & 0.00227 & 0.00167 \\
$\mathrm{Co} / \mathrm{Fe}$ & 0.000163 & 0.000381 \\
$\mathrm{Co} / \mathrm{Mn}$ & 0.0312 & 0.0265 \\
$\mathrm{Zn} / \mathrm{Mn}$ & 0.435 & 0.117 \\
$\mathrm{Mn} / \mathrm{Al}$ & 0.012 & 0.0239 \\
$\mathrm{Zn} / \mathrm{Al}$ & 0.00530 & 0.00270 \\
$\mathrm{Co} / \mathrm{Al}$ & 0.000382 & 0.000616
\end{tabular}

a Mean values of 10 analyses of Santonian ash from Cores

121-755A-5R through 121-755A-9R.

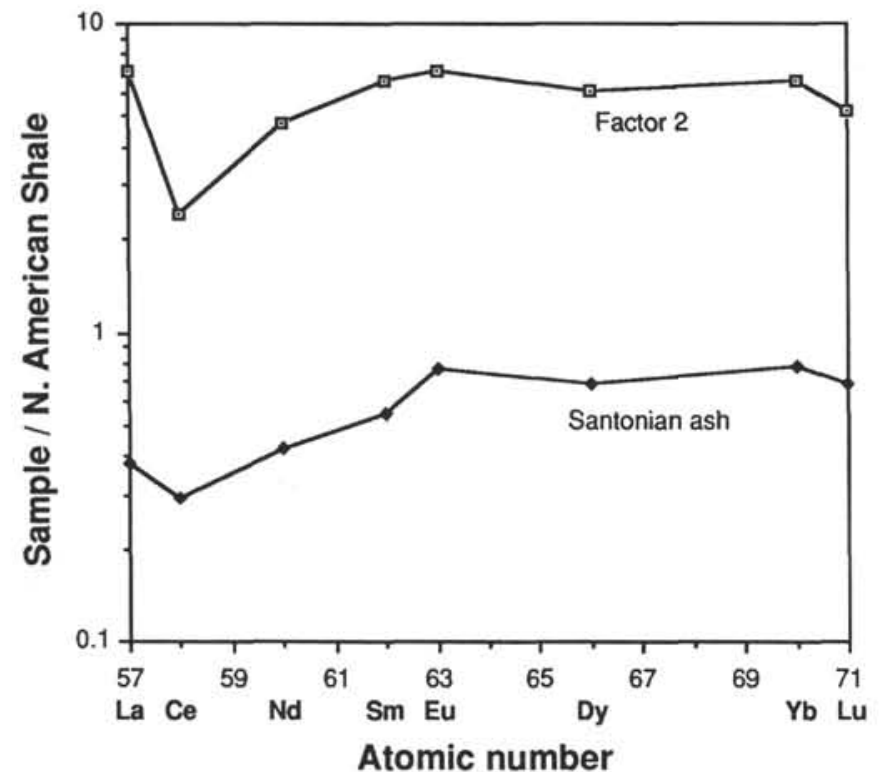

Figure 4. Comparison of REE patterns of factor 2 and Santonian ash. REE patterns are normalized to North American Shale Composite (Haskin et al., 1968). Santonian ash is the average of 10 samples from Cores 121-755A-5R through 121-755A-9R. involving other elements (e.g., $\mathrm{Al}, \mathrm{Ba}, \mathrm{Zn}, \mathrm{Co}$, and $\mathrm{Sc}$ ) that were measured. Several authors (Dymond, 1981; Greybeal and Heath, 1984; Leinen and Pisias, 1984) have summarized characteristic interelement ratios for different geochemical end members found in marine sediments. These ratios typically involve those elements that are most commonly measured in sediment analyses (e.g., $\mathrm{Fe}, \mathrm{Mn}, \mathrm{Co}, \mathrm{Ni}, \mathrm{Zn}, \mathrm{Ba}$, and $\mathrm{Al}$ ). Except for $\mathrm{Mn}$ and $\mathrm{Fe}$, however, there is actually a considerable degree of overlap between the "characteristic" interelement ratios involving $\mathrm{Co}, \mathrm{Ni}$, $\mathrm{Zn}, \mathrm{Ba}$, and $\mathrm{Al}$ for hydrothermal and hydrogenous material. For this reason, the data shown in Table 7 also include typical values for hydrogenous sediments.

The $\mathrm{Mn} / \mathrm{Fe}$ ratio is the most diagnostic geochemical ratio for hydrothermal sediments because (1) it reflects the composition of the two major metallic elements in the ferromanganese oxyhydroxide hydrothermal precipitates that form from very Fe-rich hydrothermal fluids, (2) the analytical error associated with the measurement of $\mathrm{Fe}$ and $\mathrm{Mn}$ is usually less than for trace elements, and (3) it is significantly lower than corresponding $\mathrm{Mn} / \mathrm{Fe}$ ratios observed for other common ferromanganous oxyhydroxide sedimentary phases (e.g., hydrogenous material or products of oxic and suboxic diagenesis). The $\mathrm{Mn} / \mathrm{Fe}$ ratio of factor $3(0.459)$ is very close to the range of values $(0.29-0.43)$ considered typical for hydrothermal sediments. Comparisons involving REE ratios are shown in Table 7 because recent studies have found that hydrothermal precipitates are highly efficient scavengers of REEs from both hydrothermal vent fluids and from the ambient seawater that mixes with hydrothermal fluids (Ruhlin and Owen, 1986a, 1986b; Owen and Olivarez, 1988; Olivarez and Owen, 1989). This work has also shown that hydrothermal sediments exhibit highly characteristic interelement ratios among the REEs, and these ratios

Table 7. Comparison of elemental ratios of factor 3 (Table 4) vs. literature values for hydrothermal and hydrogenous sediments.

\begin{tabular}{lllc}
\hline Ratio & Factor 3 & $\begin{array}{c}\text { Hydrothermal } \\
\text { sediments }\end{array}$ & $\begin{array}{c}\text { Hydrogenous } \\
\text { sediments }\end{array}$ \\
\hline $\mathrm{Mn} / \mathrm{Fe}$ & 0.459 & $0.29-0.43$ & $1.0-1.47$ \\
$\mathrm{Eu} / \mathrm{Yb}$ & 0.299 & $0.288-0.370$ & 0.80 \\
$\mathrm{Eu} / \mathrm{Lu}$ & 2.25 & $1.80-2.45$ & 4.44 \\
$\mathrm{Ce} / \mathrm{La}$ & 0.758 & $0.12-1.08$ & 9.73 \\
$\mathrm{Sm} / \mathrm{Nd}$ & 0.093 & $0.13-0.22$ & 0.275
\end{tabular}

a Values from Fleet (1983), Graybeal and Heath (1984), Ruhlin and Owen (1986b), Owen and Olivarez (1988), and Olivarez and Owen $(1989 \mathrm{~b})$.

b Values from Fleet (1983), Dymond et al. (1984), and Palmer and Elderfield (1986). 
are significantly different than the analogous REE ratios characteristic of hydrogenous material. The comparison of REE ratios for factor 3 vs. hydrothermal sediments and hydrogenous sediments (Table 7) illustrates this point and supports the interpretation that factor 3 is representative of hydrothermal material.

\section{Sediment Composition and Rifting Mechanisms}

The strongest evidence in support of a passive rifting mechanism for the uplift of Broken Ridge is the fact that paleodepth estimates derived from the examination of microfossils of benthic fauna suggest that the seafloor was subsiding prior to uplift (Peirce, Weissel, et al., 1989). In other words, there is no indication of pre-rift arching or shoaling as would be expected in the case of active rifting. A comparison of the ages of sediments below (mid-Eocene) and above (late Eocene) the angular unconformity at Broken Ridge indicates that rifting was very rapid. Based on sediment loading and basement subsidence considerations, Rea et al. (1990) estimated that Broken Ridge was uplifted about $2500 \mathrm{~m}$ within, at most, 2-3 m.y. Moreover, there is relatively low present-day heat flow at Broken Ridge (average $=1.04$ $\mathrm{HFU}$ ) and no systematic thermal overprinting of magnetic data (Peirce, Weissel, et al., 1989). Collectively, these results are considered tentative because of the poor preservation of certain fauna used as paleodepth indicators and a limited number of reliable geophysical measurements, but they are consistent with the passive model for the uplift of Broken Ridge.

An intriguing compositional aspect of the sediment column at Hole $752 \mathrm{~A}$ is the presence of Fe-stained sediments immediately overlying the angular unconformity. Given the tentative nature of the evidence in support of a passive rifting mechanism, it became especially important to determine whether or not the iron was derived from a hydrothermal source. Within the context of a passive rifting mechanism, the presence of a significant amount of hydrothermal materials in the post-uplift sediments would suggest that rifting and uplift occurred as a continuum at Broken Ridge, rather than as separate and distinct tectonic events. Alternatively, a hydrothermal origin for the iron could be interpreted as reflecting a time sequence of distinct tectonic events in which uplift preceded rifting; that is, a sequence thought to be characteristic of an active rifting mechanism (Sengör and Burke, 1978). Although our chemical stratigraphy results suggest that hydrothermal materials are a major component of the sediment column at Broken Ridge, they also suggest that the $\mathrm{Fe}$-stained sediments overlying the angular unconformity are derived from the weathering of ashes and are not related to a hydrothermal source.

There is at least a gross similarity between the sediment composition record at Broken Ridge and those representative of active rifting situations. The flux of the hydrothermal end member (factor 3 ) is greatest prior to the uplift of Broken Ridge and attains a maximum value below the Eocene unconformity (Fig. 3C). This pattern is suggestive of pulsations in hydrothermal activity that have been recorded elsewhere and have been related to tectonic reorganization events (Owen and Rea, 1985; Lyle et al., 1987). Reconstruction of the tectonic histories of many locations and examination of the sediment composition of these locations have revealed a clear link between active rifting events and periods of increased deposition of hydrothermal materials (some at oregrade levels) that preceded and/or accompanied these events (Rona and Richardson, 1978; Rona et al., 1983; Lyle et al., 1987; Olivarez and Owen, 1989). For example, Lyle et al. (1987) examined the Neogene history of hydrothermal deposition in association with tectonic reorganizations along the East Pacific Rise by modeling the deposition of hydrothermal $\mathrm{Mn}$ in ridge flank sediments as a function of distance from the ridge axis. Their results indicate the occurrence of episodes during which the deposition of hydrothermal materials was as much as 20 times higher than equivalent Holocene deposition. Our results indicate that the maximum flux of hydrothermal materials at Broken Ridge is about 3 times greater than early Eocene background levels; however, this peak occurs at about $55.4 \mathrm{Ma}$, or about $10 \mathrm{~m} . \mathrm{y}$. prior to the estimated time of $45 \mathrm{Ma}$ for ridge uplift (Peirce, Weissel, et al., 1989). The youngest sample below the unconformity analyzed in this study corresponds to an age of about 55.3 Ma. Because of this 10-m.y. gap in sample coverage, it is not possible to determine if the peak at $55.4 \mathrm{Ma}$ implies that hydrothermal circulation diminished some $10 \mathrm{~m} . \mathrm{y}$. before uplift or if there were other, perhaps more intense, hydrothermal pulsations closer in time to ridge uplift. We plan to address this problem in future studies by examining sediments recovered at Hole $753 \mathrm{~A}$ which were deposited between 47.0 and $48.8 \mathrm{Ma}$ (Peirce, Weissel, et al., 1989)

\section{SUMMARY}

Sediments deposited below and above the angular unconformity that denotes the uplift of Broken Ridge are composed of a mixture of three major geochemical end members. An examination of key interelement ratios for each of these end members suggests that they represent the following sedimentary components: (1) a biogenic component, (2) a volcanogenic component chemically similar to Santonian ash, and (3) a hydrothermal component. The MAR of the biogenic component is consistent with shipboard observations that note an almost complete absence of chert layers, diatoms, and other siliceous microfossils in sediments younger than early Eocene in age (Peirce, Weissel, et al., 1989). We estimate that the rifting and uplift of Broken Ridge resulted in a nearly thirtyfold reduction in the deposition of noncarbonate biogenic material. This drastic change in biogenic sedimentation, from accumulation rates of 1.1 to $0.04 \mathrm{~g} / \mathrm{cm}^{2} / 1000$ yr (Fig. 3A), may be partly explained by the movement of the ridge away from productive high-latitude regions or by a reduction in bathymetrically induced upwelling coincident with subsidence of the ridge (Rea et al., 1990).

The Fe-stained sediment overlying the middle Eocene angular unconformity is primarily composed of sediment derived from the subaerial or shallow marine weathering, erosion, and redeposition of Santonian ash and/or other chemically similar volcanogenic material. The REE pattern of this Fe-rich material suggests that the ash has been altered to some extent via interaction with seawater. The exposure of large amounts of Santonian ash during the Eocene uplift event is consistent with estimates of $2500 \mathrm{~m}$ of vertical uplift calculated using passive uplift mechanism assumptions (Weissel and Karner, 1989; Rea et al., 1990).

The greatest flux of hydrothermal materials is recorded in the sediments below the angular unconformity at Broken Ridge. Both the existence of a hydrothermal compositional end member in these sediments and the relative flux pattern of this component suggest that the uplift of Broken Ridge was preceded by a significant amount of rifting during which faulting and fracturing of the lithosphere led to enhanced hydrothermal circulation. This time sequence of events is consistent with (but not necessarily diagnostic of) the passive model for lithospheric rifting and uplift.

\section{REFERENCES}

Boström, K., Joensuu, D., Moore, C., Boström, B., Dalziel, M., and Horowitz, A., 1973. Geochemistry of barium in pelagic sediments. Lithos, 6:159-174.

Chen, J. C., and Owen, R. M., 1989. The hydrothermal component in ferromanganese nodules from the southeast Pacific Ocean. Geochim. Cosmochim. Acta, 53:1299-1305.

Dams, R., and Robbins, J. A., 1970. Nondestructive activation analysis of environmental samples. Univ. Mich. Great Lakes Res. Div. Tech. Rept., 48:1-92. 
Dehairs, R., Chesselet, R., and Jedwab, J., 1980. Discrete suspended particles of barite and the barium cycle in the open ocean. Earth Planet. Sci. Lett., 49:528-550.

Desprairies, A., and Bonnot-Courtois, C., 1980. Relation entre la composition des smectites d'alteration sous-marine et leur cortege de terres rares. Earth Planet. Sci. Lett., 48:124-130.

Dymond, J., 1981. The geochemistry of Nazca plate sediments: an evaluation of hydrothermal, biogenic, detrital, and hydrogenous sources. In Kulm, L. D., Dymond, J., Dasch, D. M., and Hussong, D. M. (Eds.), Nazca Plate: Crustal Formation and Andean Convergence: Geol. Soc. Am. Mem., 154:133-174.

Dymond, J., Lyle, M., Finney, B., Piper, D. Z., Murphy, K., Conard, R., and Pisias, N., 1984. Ferromanganese nodules from MANOP Sites H, $\mathrm{S}$, and $\mathrm{R}-$ control of mineralogical and chemical composition by multiple accretionary processes. Geochim. Cosmochim. Acta, 48:931-950.

Fleet, A. J., 1983. Hydrothermal and hydrogenous ferromanganese deposits: do they form a continuum? The rare earth element evidence. In Rona, P. A., Boström, K., Laubier, L., and Smith, K. L., Jr. (Eds.), Hydrothermal Processes at Seafloor Spreading Centers: New York (Plenum), 535-555.

Fleet, A. J., Henderson, P., and Kempe, D.R.C., 1976. Rare earth element and related chemistry of some drilled southern Indian Ocean basalts and volcanogenic sediments. J. Geophys. Res., 81:4257-4268.

Gordon, C. E., Randle, K., Goles, G. D., Corliss, J. B., Beesen, M. H., and Oxley, S. S., 1968. Instrumental analysis of standard rocks with high resolution X-ray detectors. Geochim. Cosmochim. Acta, 32:364-396.

Graybeal, A. L., and Heath, G. R., 1984. Remobilization of transition metals in surficial pelagic sediments from the eastern Pacific. Geochim. Cosmochim. Acta, 48:965-975.

Gurvich, Y. G., Bogdanov, Y. A., and Lisitzin, A. P., 1978. Behavior of barium in recent sedimentation in the Pacific. Geokhimiya, 3:359-374 [translation by Scripta Publ.].

Haskin, L. A., Wildeman, T. R., and Haskin, M. A., 1968. An accurate procedure for the determination of the rare earths by neutron activation. J. Radioanal. Chem., 1:337-348.

Houtz, R. E., Hayes, D. E., and Markl, R. G., 1977. Kerguelen Plateau bathymetry, sediment distribution and crustal structure. Mar. Geol,, 25:95-130.

Kennett, J., 1982. Marine Geology: Englewood Cliffs, NJ (Prentice Hall).

Leinen, M., and Pisias, N., 1984. An objective technique for determining end-member compositions and for partitioning sediments according to their sources. Geochim. Cosmochim. Acta, 48:47-62.

Ludden, J. N., and Thompson, G., 1978. Behavior of rare earth elements during submarine weathering of tholeiitic basalt. Nature, 274:147149.

Lyle, M., Leinen, M., Owen, R. M., and Rea, D. K., 1987. Late Tertiary history of hydrothermal deposition at the East Pacific Rise: correlation to volcano-tectonic events. Geophys. Res. Lett., 14:595-598.

Martin, J. H., and Knauer, G. A., 1973. The elemental composition of plankton. Geochim. Cosmochim. Acta, 37:1639-1653.

Mutter, J. C., and Cande, S. C., 1983. The early opening between Broken Ridge and Kerguelen Plateau. Earth Planet. Sci. Lett., 65:369-376.
Olivarez, A. M., and Owen, R. M., 1989. REE/Fe variations in hydrothermal sediments: implications for the REE content of seawater. Geochim. Cosmochim. Acta, 53:757-762.

Owen, R. M., and Olivarez, A. M., 1988. Geochemistry of rare earth elements in Pacific hydrothermal sediments. Mar. Chem., 25:183196.

Owen, R. M., and Rea, D. K., 1985. Sea-floor hydrothermal activity links climate to tectonics: the Eocene $\mathrm{CO}_{2}$ greenhouse. Science, 227:166169.

Owen, R. M., and Ruhlin, D. E., 1986. Interlaboratory comparison of Leg 92 standard sediment sample analyses. In Leinen, M., Rea, D. K., et al., Init. Repts. DSDP, 92: Washington (U.S. Govt. Printing Office), 353-354.

Palmer, M. R., and Elderfield, H., 1986. Rare earth elements and neodymium isotopes in ferromanganese oxide coatings of Cenozoic foraminifera from the Atlantic Ocean. Geochim. Cosmochim. Acta, 50:409-417.

Peirce, J., Weissel, J., et al., 1989. Proc. ODP, Init. Repts., 121: College Station, TX (Ocean Drilling Program).

Rea, D. K., Dehn, J., Driscoll, N., Farrell, J., Janecek, T., Owen, R. M., Pospichal, J. L., Resiwati, P., and the ODP Leg 121 Scientific Party, 1990. Paleoceanography of the eastern Indian Ocean from ODP Leg 121 drilling on Broken Ridge. Geol. Soc. Am. Bull., 102:679-690.

Riley, J. P., and Roth, I., 1971. The distribution of trace elements in some species of phytoplankton grown in culture. J. Mar. Biol. Assoc. U.K., 51:63-72.

Rona, P. A., Boström, K., Laubier, L., and Smith, K. L., Jr. (Eds.), 1983. Hydrothermal Processes at Seafloor Spreading Centers: New York (Plenum).

Rona, P. A., and Richardson, E. S., 1978. Early Cenozoic global plate reorganization. Earth Planet. Sci. Lett., 40:1-11.

Ruhlin, D. E., and Owen, R. M., 1986a. Factors influencing the rare earth element composition of hydrothermal precipitates, East Pacific Rise. In Leinen, M., Rea, D. K., et al., Init. Repts. DSDP, 92: Washington (U.S. Govt. Printing Office), 383-389.

1986b. The rare earth element geochemistry of hydrothermal sediments from the East Pacific Rise: examination of a seawater scavenging mechanism. Geochim. Cosmochim. Acta, 50:393-400.

Schmitz, B., 1987. Barium, equatorial high productivity, and the northward wandering of the Indian continent. Paleoceanography, 2:63-77.

Sengör, A.H.C., and Burke, K., 1978. Relative timing of rifting and volcanism on Earth and its tectonic implications. Geophys. Res. Lett., $5: 419-421$.

Shimizu, H., and Masuda, A., 1977. Cerium in chert as an indication of marine environment of its formation. Nature, 266:346-348.

Weissel, J. K., and Karner, G. D., 1985. Drilling on Broken Ridge to evaluate theoretical models for rifting. JOIDES Drilling Prop., 135B. 1989. Flexural uplift of ridge flanks due to the mechanical unloading of the lithosphere during extension. J. Geophys. Res., 94:13919-13950.

Date of initial receipt: 1 March 1990

Date of acceptance: 9 November 1990

Ms 121B-131 